\title{
Credit Risk Management Practices and Performance of Commercial Banks in South Sudan
}

\author{
Maurice Olobo ${ }^{1 *}$, Gerald Karyeija ${ }^{1}$, Protazio Sande ${ }^{1}$, Steven Khoch ${ }^{2}$ \\ ${ }^{1}$ School of Management Science, Uganda Management Institute (UMI), Kampala, Uganda \\ ${ }^{2}$ School of Business, Uganda Christian University, Mukono, Uganda \\ Email: ^olobomaurices2005@gmail.com, gerald.karyeija@gmail.com, psande@ira.go.ug, stevenkhoch@gmail.com
}

How to cite this paper: Olobo, M., Karyeija, G., Sande, P., \& Khoch, S. (2021). Credit Risk Management Practices and Performance of Commercial Banks in South Sudan. Journal of Financial Risk Management, 10, 306-316.

https://doi.org/10.4236/jfrm.2021.103018

Received: May 18, 2021

Accepted: September 10, 2021

Published: September 13, 2021

Copyright $\odot 2021$ by author(s) and ScientificResearch Publishing Inc.

This work is licensed under the

CreativeCommons Attribution

International

License (CC BY 4.0).

http://creativecommons.org/licenses/by/4.0/

\section{(c) (i) Open Access}

\begin{abstract}
The study was set to examine the extent to which Credit Risk Management Practices influence banks' performance in South Sudan. Credit Risk Management practices were looked at in terms of Credit Risk Identification (CRI) Credit Risk Assessment (CRA) and Credit Risk Control (CRC). The study applied a cross-sectional survey design with 124 respondents linked to the Credit process across 7 sampled banks in Juba. Cluster, purposive and sample random techniques were employed in gathering data using Structured questionnaires and interview guides. The study revealed a strong positive correlation between risk management practices and bank performance $(r=0.959$; $p$-value $=0.000$ which is less than 0.01). Credit Risk Assessment (CRA), Credit Risk Identification and Credit Risk Control all revealed significant results at $\mathrm{r}=0.932$ at $p$-value $=0.000 ; \mathrm{r}=0.977$ at $p$-value $=0.000$. The study further revealed that a unit increase in CRI and CRA and CRC, increased bank performance by $35.8 \%, 25.3 \%$ and $37.1 \%$ respectively. While CRI $=(\beta=0.358$ and $p=0.000)$ and CRA $(\beta=0.253$ and $p=0.000)$ seamed to drive growth of the asset book, CRC influenced Asset Quality by $(\beta=0.371$ and $p=0.000)$.
\end{abstract}

\section{Keywords}

Credit Risk Identification, Credit Risk Assessment, Credit Risk Control, Asset Book

\section{Introduction}

In the wake of modern banking practices, Credit has played a pivotal role in bank performance given the volume of bank business that is centered on credit. To this end, portfolio performance continues to attract attention from scholars and pol- 
icy-makers. (Abraham \& Anifowose, 2020), continue to emphasize the need for well-capitalized financial institutions as a building block to sustained asset quality. The core business of financial institutions is to advance credit and this exposes to risk of Nonperforming Assets (NPAs) when then attracts a provision rate, which in turn affects the capital of the institution (Area, 2016). Financial institutions, therefore, need to exercise caution while advancing credit. Lending practices need to be studied in intricate detail to ensure good practices are adopted across the industry (Saba, Kouser, \& Azeem, 2012; Rannong \& Phuenngam, 2009).

Credit Risk Management has evolved over time with new concepts that encompass review and analysis of portfolio (Egesa, 2009). Several theories have come up to challenge and affirm portfolio performance (Tejvan, 2013; Boahene, Dasah, \& Agyei, 2012; Derega, 2010; Bichanga \& Kimani, 2013) who all note the extent to which local financial institutions are undermined by dominant international financial intuitions hence increasing the contagion effect of Non-performing Assets. (Gahamanyi et al., 2009) points out that liberalization of the financial sector increased investment but also created credit challenges in form of inadequate risk management challenges. Furthermore (Longstaff, 2010; Almunia et al., 2010) all point to deregulation as the driver for credit supply and demand imbalance coupled with poor risk management practices as a major factor in driving the nonperformance of financial institutions.

The study attempts to establish the Credit Risk Management Practices that are prevalent in the industry and measure the extent to which these measures are affected in ensuring Quality portfolio while driving portfolio growth at the same time. The balance between Quality portfolio and growth has to be attained to ensure a healthy and sustainable financial sector. The motivation for this study stems from empirical evidence, which posits that the parametric and non-parametric approaches for measuring Credit Risk Management Practices and Bank Performance may not always produce the same result and have obvious implications for policy formulation.

\section{Literature Review and Theoretical Framework}

\subsection{Theoretical Framework}

The study was mainly guided by the Markowitz Portfolio Theory (MPT) of 1952. The theory was later supported by the Agency theory developed by (Shapiro, 2005). The theory assumes investors optimize their returns by reducing risk. It further contends that when various uncorrelated assets are combined in a portfolio, risks are lowered and returns improve. In the context of financial institutions, diversification helps reduce asset correlations hence lowering expected risk (Mercer, 2014; Nnanwa, 2018). However, studies by (Faulkenberry, 2018) indicates that over diversification of portfolio may increase the risk just as much as under diversification. He emphasized an appropriate balance to be achieved in diversification placing the portfolio size into consideration as well as institution- 
al capital.

\subsection{Literature Review}

(Chen et al, 2009) have defined portfolio performance as the rate at which a Financial Intuition is able to advance credit and explore new opportunities. (Potvin \& Hasni, 2014), notes the dimension of performance which include Non-performing Loans (NPL) and Provisions for bad Loans which have a negative impact on the Financial institutions Income statement or the capital position of the Institution. Several studies have measured performance by looking at Nonperforming Assets (NPA), Loan Loss provisions, Portfolio at Risk and profitability ratios like Return on assets, Return on equity (Warue, 2013; Guy \& Lowe, 2011; Kjosevski \& Petkovski, 2017; Saurina et al., 2006). Scholars like (Afriyie \& Akotey, 2012; Hitchcock \& Simpson, 2014; Saba, Kouser, \& Azeem, 2012), have affirmed that NPL and NPA are used interchangeably since both mean the same thing. However they have further gone ahead to indicate that loans that meet the conditions of 90 days and above are classified as NPL or NPA. However other scholars like (Alexander \& Pézier, 2003; Rajeev \& Mahesh, 2010; Karki, 2019) all contend that some countries observe shorter delays of more than 30 days, 60 days as being classified at NPA/NPL. In the context of Uganda, a 90 days structure is observed where provisions are applied at $100 \%$ on the loan that is over 90 days.

Portfolio performance in many financial institutions have been liked to variety of factors which include Credit Risk management, interest rates, market conditions, institutional level of risk such as knowledge and skill, risk perception and ethics (Louzis et al., 2012; Fofack \& Fofack, 2005; Saurina et al., 2006; Warue, 2013). Scholars such as (Antunes \& Gonzelaz, 2015) point out the importance of objectivity in achieving institutional goals with the guidance of the Risk Management Framework. The framework outlines the importance of understanding internal and external environment, setting objectives, Conducting Risk Analysis, Risk Treatment and Risk Controls activities, information and communication as well as monitoring. Credit Risk Management helps to reduce the lending institution's risk adjusted pricing rate of return by keeping the risk within acceptable parameters.

Several studies have been done on risk identification as being the first step in the risk management process. The output of identification is risk register which must be communicated to the relevant stake holders (Chapman et al., 2001; Bessis et al., 2002). Furthermore (Geitangi, 2015), add that the process of risk identification takes into account checking of credit applications, reviewing proposals for credit and assessing potential risk exposures, analyzing repayment characters and their credit history. (Segal, 2011) add that contextualization, communication and documentation are crucial in the process of identifying risk. Credit Assessment is the second stage and it involves checking for credit worthiness. (Tetteh, 2017; Bahabadi \& Mohammadi, 2016; Hsu, Ou, \& Ou, 2015) all postulate that this stage involves measuring, ranking risk in accordance to magnitude and frequency of occurrence. Furthermore, (Mwangi, 2012) in a study raised that's risk 
can be measured qualitatively and quantitatively. This process involves engaging key stake holders which is provided for in the risk management framework (Ongeri et al., 2021). The final stage is Credit Risk Control (CRC) which gives protection to exposure. This is done by applying physical standards, tools, techniques, training to help prevent a loss from occurring (Engels et al., 2011).

\section{Methodology}

\subsection{Data}

The data employed for this study is drawn from already existing banks in Juba South Sudan. A sample of 6 banks was selected using simple random sampling technique. Within the selected banks, Cluster sampling techniques was employed to cluster respondents who are either directly linked to the credit process or indirectly such as the control rolls (audit/risk/compliance/credit committees of management). Out of the 30 banks in Juba, 28 banks were randomly selected to participate in the study. Within each bank, the credit functions were clustered along with other roles that are linked to credit for each of the banks. Within each cluster simple random sampling was employed where 124 respondents answered the Questionnaires. Interview guides were also administered to key informers. A total of 14 interviews were conducted with key representatives from the sampled banks. The data was analyzed using descriptive statistics, correlational and regression techniques.

\subsection{Model Specification}

The model used in the study was simple linear model as shown below (Figure $1)$.

\subsection{Reliability and Validity}

To be sure of the measures, Cronbach's alpha co-efficient was computed for all variables and it confirmed the reliability of the instrument that had been used in the study because all variables showed values above 0.8 . Validity was obtained using Content Validity Index that was obtained as 0.906 above the acceptable limit of 0.7. As seen in the table (Table 1).

The research instrument that was used to test for validity and reliability was adopted from various studies that tested different aspects of Risk identification, Risk assessment and Risk Control. The researcher picked the questions that best measure the above constructs.

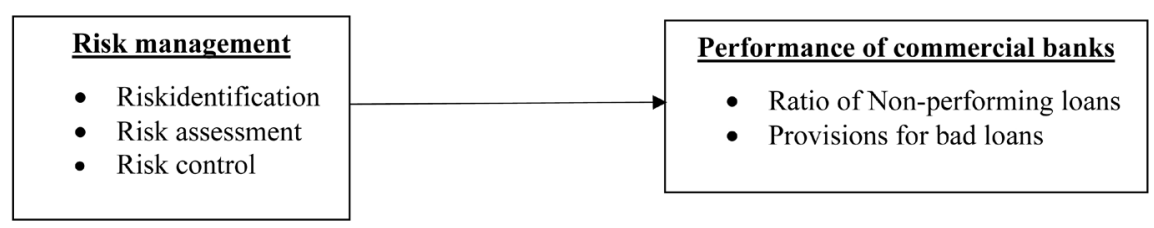

Figure 1. Conceptual framework. Source: modified from (Abdou, 2009; Al-Tamini \& Al-Mazrooei, 2007; Bhattacharya et al., 2011). 
Table 1. Reliability test results.

\begin{tabular}{cc}
\hline Variables & Cronbach alpha coefficient \\
\hline Risk identification & 0.867 \\
Risk assessment & 0.842 \\
Risk control & 0.815 \\
\hline
\end{tabular}

\subsection{Data Analysis}

Data was analyzed using three levels. The first level had descriptive statistics mainly mean and standard deviation. The second level was for relational statistics using Pearson' Product Moment Correlation Coefficient to establish the relationship between risk factors and commercial bank performance. Thirdly on establishing whether relationship existed, hypotheses were tested using multiple regression analysis to establish the order of casual influence of Risk factors on Bank performance.

\section{Empirical Findings}

From the study, most of the respondents associated with the credit role were $55.6 \%$ male and $44.4 \%$ female. The age distribution showed that most of the respondents were between the age bracket of 26-35 years of age (50\%). Most of the respondents had a fair understanding of risk processes and they had a bachelor's degree certification (51.6\%) with 4 to 5 years' experience $(37.9 \%)$ in the credit function respectively.

From the findings, the study investigated risk identification mechanism in the sampled banks. The results showed that most institutions have clear risk identification framework (Mean $=4.26$; Std $=0.636)$, risk management strategy (mean $=4.32$; Std $=0.592)$, Risk assignments $($ Mean $=4.16$; Std $=0.692)$. However generally the study revealed that on average all banks demonstrated a presence of some form of risk identification structure (Mean $=3.99$; Std $=0.852)$. The level of variability was also observed to be high in most institutions as shown in Table 2. This indicated that much as risk structures were present, not everyone in the credit role appreciated risk identification as some respondents were seen prioritizing portfolio growth and less on risk identification and recording.

The study further looked at the Credit assessment process, the study revealed that assessment of risk was being done adequately (mean $=3.94$; $\mathrm{Std}=0.901$ ) as shown in Table 3. However, there was contention over the measurement of credit risk $($ mean $=2.01$; $\mathrm{Std}=1.164)$. Most respondents revealed that various intuitions were applying various differing methods of Quantifying risk. Some institutions preferred to have qualitative assessments of risk while little was being done to quantify risk in the sector.

Furthermore on issues of Credit Risk Control (CRC), the study revealed that CRC control was revealed to be low in most institutions as most the respondents were more focused on growing the portfolio. The study revealed that most 
Table 2. Relationship between credit risk management practices and performance of commercial banks.

\begin{tabular}{|c|c|c|c|c|c|}
\hline & & $\begin{array}{c}\text { Credit risk } \\
\text { identification }\end{array}$ & $\begin{array}{l}\text { Credit risk } \\
\text { assessment }\end{array}$ & $\begin{array}{l}\text { Credit risk } \\
\text { control }\end{array}$ & $\begin{array}{l}\text { Performance } \\
\text { of commercial } \\
\text { banks }\end{array}$ \\
\hline \multirow{3}{*}{$\begin{array}{c}\text { Credit risk } \\
\text { identification }\end{array}$} & Pearson correlation & 1 & & & \\
\hline & Sig. (2-tailed) & & & & \\
\hline & $\mathrm{N}$ & 124 & & & \\
\hline \multirow{3}{*}{$\begin{array}{l}\text { Credit risk } \\
\text { assessment }\end{array}$} & Pearson correlation & $0.924^{* *}$ & 1 & & \\
\hline & Sig. (2-tailed) & 0.000 & & & \\
\hline & $\mathrm{N}$ & 124 & 124 & & \\
\hline \multirow{3}{*}{$\begin{array}{c}\text { Credit risk } \\
\text { control }\end{array}$} & Pearson correlation & $0.984^{\star *}$ & $0.989^{* *}$ & 1 & \\
\hline & Sig. (2-tailed) & 0.000 & 0.000 & & \\
\hline & $\mathrm{N}$ & 124 & 124 & 124 & \\
\hline \multirow{3}{*}{$\begin{array}{c}\text { Performance } \\
\text { of commercial } \\
\text { banks }\end{array}$} & Pearson correlation & $0.959^{* *}$ & $0.932^{* *}$ & $0.977^{* *}$ & 1 \\
\hline & Sig. (2-tailed) & 0.000 & 0.000 & 0.000 & \\
\hline & $\mathrm{N}$ & 124 & 124 & 124 & 124 \\
\hline
\end{tabular}

${ }^{* *}$ Correlation is significant at the 0.01 level (2-tailed).

Table 3. Casual effect of the framework dimensions.

\begin{tabular}{|c|c|c|c|c|c|c|}
\hline \multicolumn{7}{|c|}{ Coefficients $^{\mathrm{a}}$} \\
\hline & \multirow[t]{2}{*}{ Model } & \multicolumn{2}{|c|}{$\begin{array}{l}\text { Unstandardized } \\
\text { coefficients }\end{array}$} & \multirow{2}{*}{$\begin{array}{c}\text { Standardized } \\
\text { coefficients }\end{array}$} & \multirow[t]{2}{*}{$\mathrm{T}$} & \multirow[t]{2}{*}{ Sig. } \\
\hline & & B & Std. Error & & & \\
\hline \multirow{4}{*}{1} & (Constant) & 1.725 & 0.379 & & 0.000 & 1.000 \\
\hline & Risk identification & 0.358 & 0.048 & 0.358 & 2.058 & 0.000 \\
\hline & Risk assessment & 0.253 & 0.052 & 0.253 & 3.521 & 0.000 \\
\hline & Risk control & 0.371 & 0.043 & 0.371 & 2.098 & 0.000 \\
\hline
\end{tabular}

${ }^{a}$ Dependent variable: performance of commercial banks. Source: Primary Data 2019.

institutions agreed on the nature of risks they were taking and acknowledged that measured were in place to control such risks. Some of the aspects they agreed on included assignment of guarantors (Mean $=4.23$; Std $=0.723$ ), Insurance (Mean $=4.09$; Std $=0.625)$. However, generally credit monitoring and follow-up was considered to be ineffective or even nonexistent in some parts of bank operations.

\subsection{Relational Statistics of Variables}

To establish the relationship between company factors and competitiveness in SMEs, Pearson's Product Moment Correlation Coefficient pre-ceded by testing for the linearity with scatter diagrams.

The linear pattern emerged between both variables revealing a relationship. 
Pearson's-Product moment correlation coefficient was computed. The study revealed that credit risk management practices had a strong positive correlation to bank performance at $99 \%$ level of significance.

\subsection{Multiple Regression Results}

The factors that were used to determine credit risk management practices included credit risk identification, credit risk assessment and credit risk control. All these factors scored a strong positive correction to bank performance at $p$-value $=0.000$.

The study further advanced to establish whether the relationship that exists is a course effect relationship by computing multiple regression analysis. Here the hypothesis will be rejected or upheld. The table (Table 3) shows the results.

The study revealed that credit risk management practices' constructs were risk identification, risk assessment and risk control. Based on the beta value, the factor dimensions were ranked in order of course to bank performance. Credit Risk Control (CRC) was ranked first (beta value 0.371), followed by Credit Risk Identification (CRI) with a beta value 0.358 , then Credit Risk Assessment (CRA) with a beta value 0.253 . The regression model therefore would be: $Y=\beta_{0}+0.358 \mathrm{CRI}+0.253 \mathrm{CRA}+0.371 \mathrm{CRC}+\cdots+\beta_{n} X_{n}+\varepsilon$.

\section{Discussions of the Findings}

From the study, the major findings indicated that most financial institutions did demonstrate a presence of Credit Risk Management structures. Several interviews indicated that Risk Identification Framework (RIF) were in place (Mean = 4.26; Std $=0.636$ ), Risk Management Strategy $(\mathrm{RMS})$ was also in place (mean = 4.32; Std $=0.592$ ), Risk Assignments (RA) was also being done. This was consistent with studies done by (Rosman, 2009; Kaplan \& Mikes, 2012; Van Greuning \& Bratanovic, 2009). However, much as the structures and polies were in place, the study did not assess the control environment effectiveness. This was manifested by high variations in the standard deviation that can be seen in the study. This is consistent with (Ashraf, Zheng, \& Arshad, 2016; Adhikari \& Agrawal, 2016; Illiashenko \& Laidroo, 2020) who all emphasized the importance of the cultural environment is impacting the Risk Management Practices.

The study further showed that the correlational effect of Risk Management Practices which involved Risk Identification, Risk Assessment (RA) and Risk Control (RC) were all statistically significant at $99 \%$. This study was consistent with other studies by (Yousfi, 2015; Taiwo et al., 2017), whom all emphasized that Risk Management practices would enhance disclosure. However, some studies disagreed stating that strict Risk Management Practices would inhibit business growth (Kedia \& Chhokar, 1986; Bushman \& Williams, 2015) who all emphasized the balance between Risk Management and Business growth. The study further indicated the dimensions of the Risk Management Practices were ranked in order of effect on Bank Performance. Credit Risk Control (CRC) was ranked 
first (beta value 0.371), followed by Credit Risk Identification (CRI) (beta value 0.358), then Credit Risk Assessment (CRA) (beta value 0.253). This was consistent with (Wachira, 2017; Taiwo et al., 2017).

In conclusion, credit Risk management as a structural requirement needs to be enhanced while balancing the business requirements with controls.

\section{Limitation of the Study}

The study focused was on the existence of risk management systems within the credit function. Such systems included Credit Risk Identification, Credit Risk Assessment, Credit Risk Control and their influence on performance. However, the study did not venture into Bank performance in terms of Non-performing Assets (NPAs), Provisions associated with Non-performing Assets. Furthermore, the study focused more on the adequacy of Risk Management Practices within the banks and did not venture into the contribution of human factors in influencing Risk Management Practices.

\section{Conflicts of Interest}

The authors declare no conflicts of interest regarding the publication of this paper.

\section{References}

Abdou, H. A. (2009). Genetic Programming for Credit Scoring: The Case of Egyptian Public Sector Banks. Expert Systems with Applications, 36, 11402-11417. https://doi.org/10.1016/j.eswa.2009.01.076

Abraham, E. A., \& Anifowose, O. M. (2020). Assessment of Risk Management on Construction Project in Abuja, Nigeria. Proceedings of the 5th Research conference of the NIQS (RECON 5), 546-558.

Adhikari, B. K., \& Agrawal, A. (2016). Does Local Religiosity Matter for Bank Risk-Taking? Journal of Corporate Finance, 38, 272-293. https://doi.org/10.1016/j.jcorpfin.2016.01.009

Afriyie, H. O., \& Akotey, J. O. (2012). Credit Risk Management and Profitability of Selected Rural Banks in Ghana. Catholic University College of Ghana.

Alexander, C., \& Pézier, J. (2003). On the Aggregation of Firm-Wide Market and Credit Risks. ISMA Centre Discussion, Article No. DP2003-13. https://doi.org/10.2139/ssrn.478381

Almunia, M., Benetrix, A., Eichengreen, B., O’Rourke, K. H., \& Rua, G. (2010). From Great Depression to Great Credit Crisis: Similarities, Differences and Lessons. Economic Policy, 25, 219-265. https://doi.org/10.1111/j.1468-0327.2010.00242.x

Al-Tamini, M., \& Al-Mazrooei, E. (2007). The Professional Risk Managers' Handbook: A Comprehensive Guide to Current Theory and Best Practices. PRMIA Publications.

Antunes, R., \& Gonzalez, V. (2015). A Production Model for Construction: A Theoretical Framework. Buildings, 5, 209-228. https://doi.org/10.3390/buildings5010209

Area, A. (2016). Bank Specific Factors Affecting Loan Performance: A Case Study of Uganda Development Bank Limited. Uganda Technology and Management University.

Ashraf, B. N., Zheng, C., \& Arshad, S. (2016). Effects of National Culture on Bank Risk-Tak- 
ing Behavior. Research in International Business and Finance, 37, 309-326. https://doi.org/10.1016/j.ribaf.2016.01.015

Bahabadi, E. A., \& Mohammadi, M. (2016). Customer Ranking Based on Credit Risk Using MCDM Methods. Management and Administrative Sciences Review, 5, 173-185.

Bessis, D., Digne, F., \& Michel, J. (2002). Springer Theory in Braid Groups and the Birman-Ko-Lee Monoid. Pacific Journal of Mathematics, 205, 287-309. https://doi.org/10.2140/pjm.2002.205.287

Bhattacharya, S., Hyodo, M., Goda, K., Tazoh, T., \& Taylor, C. A. (2011). Liquefaction of Soil in the Tokyo Bay Area from the 2011 Tohoku (Japan) Earthquake. Soil Dynamics and Earthquake Engineering, 31, 1618-1628. https://doi.org/10.1016/j.soildyn.2011.06.006

Bichanga, W. O., \& Kimani, A. W. (2013). Effectiveness of ISO 9001: 2008 Certification on Service Delivery of Public Universities in Kenya. European Journal of Business and Management, 5, 232-242.

Boahene, S. H., Dasah, J., \& Agyei, S. K. (2012). Credit Risk and Profitability of Selected Banks in Ghana. Research Journal of Finance and Accounting, 3, 6-14.

Bushman, R. M., \& Williams, C. D. (2015). Delayed Expected Loss Recognition and the Risk Profile of Banks. Journal of Accounting Research, 53, 511-553. https://doi.org/10.1111/1475-679X.12079

Chapman, W. W., Bridewell, W., Hanbury, P., Cooper, G. F., \& Buchanan, B. G. (2001). A Simple Algorithm for Identifying Negated Findings and Diseases in Discharge Summaries. Journal of Biomedical Informatics, 34, 301-310. https://doi.org/10.1006/jbin.2001.1029

Chen, J. H., Chuang, S. Y., Chen, H. J., Yeh, W. T., \& Pan, W. H. (2009). Serum Uric Acid Level as an Independent Risk Factor for All-Cause, Cardiovascular, and Ischemic Stroke Mortality: A Chinese Cohort Study. Arthritis Care \& Research, 61, 225-232. https://doi.org/10.1002/art.24164

Derega, V. (2010) The Conceptual Foundations of Public Family Policy. Public Policy and Economic Development, 250, 132-135.

Egesa, K. A. (2009). Evaluation of Uganda's Commercial Banking Sector Regulatory Environment: Implications for Commitment to the Gats. The Bank of Uganda Staff Papers, 3, 91-112.

Engels, E. A., Pfeiffer, R. M., Fraumeni, J. F., Kasiske, B. L., Israni, A. K., Snyder, J. J. et al. (2011). Spectrum of Cancer Risk among US Solid Organ Transplant Recipients. JAMA, 306, 1891-1901. https://doi.org/10.1001/jama.2011.1592

Faulkenberry, T. J. (2018). Computing Bayes Factors to Measure Evidence from Experiments: An Extension of the BIC Approximation. Biometrical Letters, 55, 31-43. https://doi.org/10.2478/bile-2018-0003

Fofack, H., \& Fofack, H. L. (2005). Nonperforming Loans in Sub-Saharan Africa: Causal Analysis and Macroeconomic Implications (Vol. 3769). World Bank Publications. https://doi.org/10.1596/1813-9450-3769

Gahamanyi, M., Andersson, I., \& Bergsten, C. (2009). Using Mathematics as a Tool in Rwandan Workplace Settings: The Case of Taxi Drivers. Proceedings of the 6th Congress of the European Society for Research in Mathematics Education, Lyon, 28 January-1 February 2009, 1484-149.

Geitangi, D. M. (2015). The Relationship between Credit Risk Management Practices and the Performance of Loan Portfolio of Commercial Banks in Kenya. Doctoral Dissertation, University of Nairobi. 
Guy, K., \& Lowe, S. (2011). Non-Performing Loans and Bank Stability in Barbados. Economic Review, 37, 77-99.

Hitchcock, P., \& Simpson, I. R. (2014). The Downward Influence of Stratospheric Sudden Warmings. Journal of the Atmospheric Sciences, 71, 3856-3876. https://doi.org/10.1175/JAS-D-14-0012.1

Hsu, L. C., Ou, S. L., \& Ou, Y. C. (2015). A Comprehensive Performance Evaluation and Ranking Methodology under a Sustainable Development Perspective. Journal of Business Economics \& Management, 16, 74-92. https://doi.org/10.3846/16111699.2013.848228

Illiashenko, P., \& Laidroo, L. (2020). National Culture and Bank Risk-Taking: Contradictory Case of Individualism. Research in International Business and Finance, 51, Article ID: 101069. https://doi.org/10.1016/j.ribaf.2019.101069

Kaplan, R., \& Mikes, A. (2012). Managing Risks: A New Framework. Harvard Business Review, 90, 48-60.

Karki, K. P. (2019). A Study on Nonperforming Loan Management of Commercial Banks in Nepal. Doctoral Dissertation, Tribhuvan University.

Kedia, B. L., \& Chhokar, J. (1986). Factors Inhibiting Export Performance of Firms: An Empirical Investigation. Management International Review, 4, 33-43. https://doi.org/10.1080/1406099X.2016.1246234

Kjosevski, J., \& Petkovski, M. (2017). Non-Performing Loans in Baltic States: Determinants and Macroeconomic Effects. Baltic Journal of Economics, 17, 25-44. https://doi.org/10.1080/1406099X.2016.1246234

Longstaff, F. A. (2010). The Subprime Credit Crisis and Contagion in Financial Markets. Journal of Financial Economics, 97, 436-450. https://doi.org/10.1016/j.jfineco.2010.01.002

Louzis, D. P., Vouldis, A. T., \& Metaxas, V. L. (2012). Macroeconomic and Bank-Specific Determinants of Non-Performing Loans in Greece: A Comparative Study of Mortgage, Business and Consumer Loan Portfolios. Journal of Banking \& Finance, 36, 1012-1027. https://doi.org/10.1016/j.jbankfin.2011.10.012

Mercer, J. (2014). Feeling Like a State: Social Emotion and Identity. International Theory, 6, 515-535. https://doi.org/10.1017/S1752971914000244

Mwangi, G. N. (2012). The Effect of Credit Risk Management on the Financial Performance of Commercial Banks in Kenya. Doctoral Dissertation, University of Nairobi.

Nnanwa, C. P. (2018). Mathematical Analysisin Investment Theory: Applications to the Nigerian Stock Market. Sheffield Hallam University.

Ongeri, N. B., Nyangau, A., \& Nyaboga, Y. (2021). Evaluation of the Effect of Credit Evaluation on Financial Performance of Commercial Banks in Kisii County, Kenya. International Academic Journal of Economics and Finance, 3, 345-361.

Potvin, P., \& Hasni, A. (2014). Analysis of the Decline in Interest towards School Science and Technology from Grades 5 through 11. Journal of Science Education and Technology, 23, 784-802. https://doi.org/10.1007/s10956-014-9512-x

Rajeev, M., \& Mahesh, H. P. (2010). Banking Sector Reforms and NPA: A Study of Indian Commercial Banks. Working Paper-2, The Institute for Social and Economic Change.

Ranong, P. N., \& Phuenngam, W. (2009). Critical Success Factors for Effective Risk Management Procedures in Financial Industries: A Study from the Perspectives of the Financial Institutions in Thailand.

Rosman, R. (2009). Risk Management Practices and Risk Management Processes of Islamic Banks: A Proposed Framework. International Review of Business Research Papers, 5, 242-254. 
Saba, I., Kouser, R., \& Azeem, M. (2012). Determinants of Non Performing Loans: Case of US Banking Sector. The Romanian Economic Journal, 15, 125-136.

Saurina, A., Campistol, J. M., Piera, C., Diekmann, F., Campos, B., Campos, N. et al. (2006). Conversion from Calcineurin Inhibitors to Sirolimus in Chronic Allograft Dysfunction: Changes in Glomerular Haemodynamics and Proteinuria. Nephrology Dialysis Transplantation, 21, 488-493. https://doi.org/10.1093/ndt/gfi266

Segal, E. A. (2011). Social Empathy: A Model Built on Empathy, Contextual Understanding, and Social Responsibility That Promotes Social Justice. Journal of Social Service Research, 37, 266-277. https://doi.org/10.1080/01488376.2011.564040

Shapiro, S. P. (2005). Agency Theory. Annual Review of Sociology, 31, 263-284. https://doi.org/10.1146/annurev.soc.31.041304.122159

Taiwo, J. N., Ucheaga, E. G., Achugamonu, B. U., Adetiloye, K., Okoye, O., \& Agwu, P. E. (2017). Credit Risk Management: Implications on Bank Performance and Lending Growth. Saudi Journal of Business and Management Studies, 2, 584-590.

Tejvan, P. (2013). Keynesian Economics.

Tetteh, E. K. (2017). Utilization of Microfinance Loan among Clients of the Upper Menya Krobo Rural Bank of the Eastern Region of Ghana. Doctoral Dissertation, University of Cape Coast.

Van Greuning, H., \& Bratanovic, S. B. (2009). Analyzing Banking Risk: A Framework for Assessing Corporate Governance and Financial Risk. The World Bank. https://doi.org/10.1596/978-0-8213-7728-4

Wachira, A. K. (2017). Effects of Credit Risk Management Practices on Loan Performance of Commercial Banks in Nyeri County, Kenya. European Journal of Economic and Financial Research, 2, 1-12.

Warue, B. N. (2013). The Effects of Bank Specific and Macroeconomic Factors on Nonperforming Loans in Commercial Banks in Kenya: A Comparative Panel Data Analysis. Advances in Management and Applied Economics, 3, Article No. 135.

Yousfi, I. (2015). Risk Management Practices and Financial Performance in Jordan: Empirical Evidence from Islamic Banks. Setif University. 